\title{
Morphological characterization of Eustrongylides sp. larvae (Nematoda, Dioctophymatoidea) parasite of Rhinella marina (Amphibia: Bufonidae) from Eastern Amazonia
}

\author{
Caracterização morfológica de larva de Eustrongylides sp. (Nematoda, Dioctophymatoidea) \\ parasita de Rhinella marina (Amphibia: Bufonidae) da Amazônia Oriental Brasileira
}

Francisco Tiago de Vasconcelos Melo ${ }^{1 *}$; Caroline do Socorro Barros Melo ${ }^{1}$; Luciana de Cássia Silva do Nascimento ${ }^{2}$; Elane Guerreiro Giese ${ }^{3}$; Adriano Penha Furtado ${ }^{1}$; Jeannie Nascimento dos Santos ${ }^{1}$

\begin{abstract}
${ }^{1}$ Laboratório de Biologia Celular e Helmintologia “Profa. Dra. Reinalda Marisa Lanfredi”, Instituto de Ciências Biológicas, Universidade Federal do Pará - UFPA, Belém, PA, Brasil

${ }^{2}$ Laboratório de Tecnologia Biomolecular, Instituto de Ciências Biológicas, Universidade Federal do Pará - UFPA, Belém, PA, Brasil

${ }^{3}$ Laboratório de Histologia e Embriologia Animal, Instituto de Saúde e Produção Animal, Universidade Federal Rural da Amazônia UFRA, Belém, PA, Brasil
\end{abstract}

Received July 23, 2015

Accepted September 21, 2015

\begin{abstract}
Absctract
Eustrongylides spp. nematodes have birds as final hosts and uses other vertebrates as intermediate/paratenic host (fish, amphibians and reptiles) and have zoonotic potential. In amphibians, the larvae may be located in the subcutaneous tissues, liver and mesentery, between the muscle fibres, especially in the lower limbs. Rhinella marina, which is widely observed in Brazil, has exhibited complex diversity in its helminth fauna, reflecting the unique habitat of the Amazon biome. For the first time, this study describes the morphological aspects of third-stage larvae of Eustrongylides sp. in Rhinella marina from Santa Cruz do Ararí, Marajó Archipelago, Eastern Amazonia, using light and scanning electron microscopy.
\end{abstract}

Keywords: Wild life parasites, helminth of amphibians, nematode larva, Eustrongylides.

\section{Resumo}

Os nematoides do gênero Eustrongylides tem as aves como seus hospedeiros definitivos e utilizam outros vertebrados como hospedeiros intermediários/paratênicos (peixes, anfíbios, répteis), além de apresentar potencial zoonótico. Em anfíbios, as larvas podem estar localizadas em tecidos subcutâneos, fígado, mesentério e entre fibras musculares de membros inferiores. Rhinella marina, anfíbio o qual é distribuído amplamente no Brasil, apresenta uma complexa diversidade em sua helmintofauna, refletindo o seu hábitat no bioma amazônico. O presente estudo descreve, pela primeira vez, os aspectos morfológicos das larvas de terceiro estágio de Eustrongylides sp. em $R$. marina de Santa Cruz do Arari, Arquipélago do Marajó, Amazônia Oriental Brasileira, utilizando-se microscopia de luz e microscopia eletrônica de varredura.

Palavras-chave: Parasitas e animais silvestres, helmintos de anfíbios, larva de nematoide, Eustrongylides.

The genus Eustrongylides Jägerskiöld, 1909 consists of three species: Eustrongylides tubifex Jägerskiöld, 1909, Eustrongylides ignotus Jägerskiöld, 1909 and Eustrongylides excisus Jägerskiöld, 1909, which are commonly found parasitizing birds, and uses fish, amphibians and reptiles as intermediate/paratenic hosts. These parasites also occasionally parasitise man and thus have zoonotic potential (XIONG et al., 2009). According to Xiong et al.

\footnotetext{
*Corresponding author: Francisco Tiago de Vasconcelos Melo. Laboratório de Biologia Celular e Helmintologia "Profa. Dra. Reinalda Marisa Lanfredi", Instituto de Ciências Biológicas, Universidade Federal do Pará - UFPA, Rua Augusto Corrêa, 1, Guamá, CEP 66075-110, Belém, PA, Brasil. e-mail: ftiago@ufpa.br
}

(2009), the life cycle of these parasites remains scarcely known. Nevertheless, studies have shown that these helminths use piscivorous birds as definitive hosts, oligochaetes as first intermediate hosts (L1 to L3 larval stage) and usually fish as second intermediate hosts (L4 larval stage), and also possibly amphibians and reptiles as second intermediate hosts or paratenic hosts (MORAVEC, 1994; LEZAMA \& SARABIA, 2002; FRIEND \& FRANSON, 1999).

Rhinella marina Linnaeus, 1758 is an amphibian commonly found in Brazil and presents a complex helminth fauna that reflects a unique diversity, especially in the Amazonia Biome. In the last six years, new taxa have been reported from this host (SANTOS et al., 2008, 2011; MELO et al., 2011; GOMES et al. 2013) together 
with the first report of Ortleppascaris (SILVA et al., 2013a, b). This study adds yet another component to this helminth fauna, for the first time describing morphological aspects of second-stage larvae of Eustrongylides in R. marina from the Marajó Archipelago, Eastern Amazonia.

In June 2009, 14 specimens of $R$. marina were obtained from a peridomestic area in the municipality of Santa Cruz do Arari ( $0^{\circ} 39^{\prime} 48^{\prime}$ S $\left.49^{\circ} 10^{\prime} 30^{\prime \prime} \mathrm{W}\right)$, Marajó Archipelago, State of Pará, eastern Brazilian Amazon. Nematodes recovered from cysts on the serosa of the stomach and intestines were fixed in AFA (95\% alcohol, 3\% formaldehyde and 2\% glacial acetic acid), dehydrated in an ascending series of ethyl alcohol, cleared in Aman's lactophenol and analysed under an Olympus BX41 light microscope coupled with a drawing tube. Measurements are given in millimetres, unless otherwise noted, and they are represented as mean and standard deviation with the range in parenthesis. Some nematode samples fixed in AFA were post-fixed in 1\% osmium tetroxide, dehydrated to the $\mathrm{CO}_{2}$ critical point, sputtered with gold and examined in a LEO 1459 scanning electron microscope from the René Rachou Research Institute, Oswaldo Cruz Foundation - Minas Gerais, Brazil.

\section{Eustrongylides sp. (Second-stage Larvae)}

Description (based on 10 specimens): Cylindrical body, surface with delicate transverse striations (Figures 1 and 2). Total length $8.68 \mathrm{~mm} \pm 0.52(7.46-8.46)$; total width at the end of the oesophagus $0.09 \pm 0.004 \mathrm{~mm}(0.08-0.09)$. Cephalic extremity presenting 15 sub-spherical papillae, arranged in two circles (an inner circle near the oral opening with three pairs of small papillae and an outer circle with four pairs of bulky papillae). The inner circle papillae, near the oral opening distributed into pairs of two lateral, two sub-ventral and two sub-dorsal. Four lateral, two sub-ventral and two sub-dorsal papillae in the external circle (Figures 1B, 2A-B). An additional papilla found between the two pairs of sub-ventral papillae of the outer circle (Figure $2 \mathrm{~B}$ ). Buccal capsule $0.52 \mathrm{~mm} \pm 0.07(0.42-0.66) \times 0.18 \mathrm{~mm} \pm 0.20$ (12 to 5.5$)$ followed by filarioid oesophagus $1.55 \mathrm{~mm} \pm 0.14$ $(1.22-1.73) \times 0.09 \mathrm{~mm} \pm 0.09(0.05-0.07)$ (Figure 1A-C). Nerve ring $0.80 \mathrm{~mm} \pm 0.10(0.54-0.91)$ from the anterior extremity. Excretory pore not observed. Terminal anus with rectal ampulla $1.65 \mathrm{~mm} \pm 0.19(1.28-2)$ in length (Figures $1 \mathrm{C}-\mathrm{D}$ and 2C-D). Genital primordium, not observed.

\section{Taxonomic Summary}

Superfamily: Dioctophymatoidea Railliet 1915 (Roman 1965). Family: Dioctophymatidae (Railliet, 1915).

Eustrongylides Jägerskiöld, 1909.

Eustrongylides sp. (Larvae).

Host: Rhinella marina (Amphibia, Bufonidae).

Infection site: Encysted on the serosa of stomach and intestines. Location: Santa Cruz do Arari, Pará, Brazil ( $0^{\circ} 39^{\prime} 48^{\prime \prime} \mathrm{S}$ $\left.49^{\circ} 10^{\prime} 30^{\prime \prime} \mathrm{W}\right)$.

Prevalence: $21.43 \%$ (3 of 14 hosts infected).

Range of infection: $3-7$
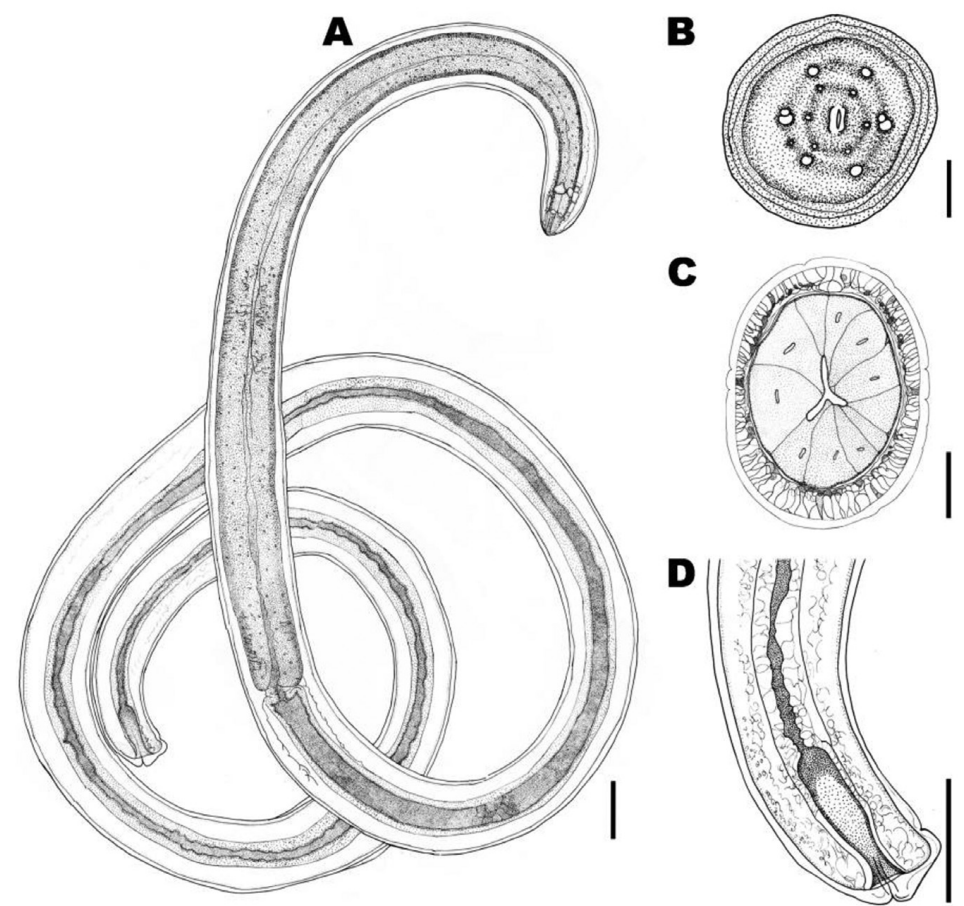

Figure 1. Line drawings of Eustrongylides sp. larvae found parasitizing Rhinella marina from Eastern Brazilian Amazon. (A) Nematode general view. Bar $=100 \mu \mathrm{m}$; (B) Detail of apical section, showing two small lips and the presence of two papillae circles: an inner circle and an outer circle. Bar $=50 \mu \mathrm{m}$; (C) Transverse section at oesophagus region, showing details of the lumen. Bar $=50 \mu \mathrm{m}$; (D) Posterior region, showing the terminal anus. Bar $=200 \mu \mathrm{m}$. 

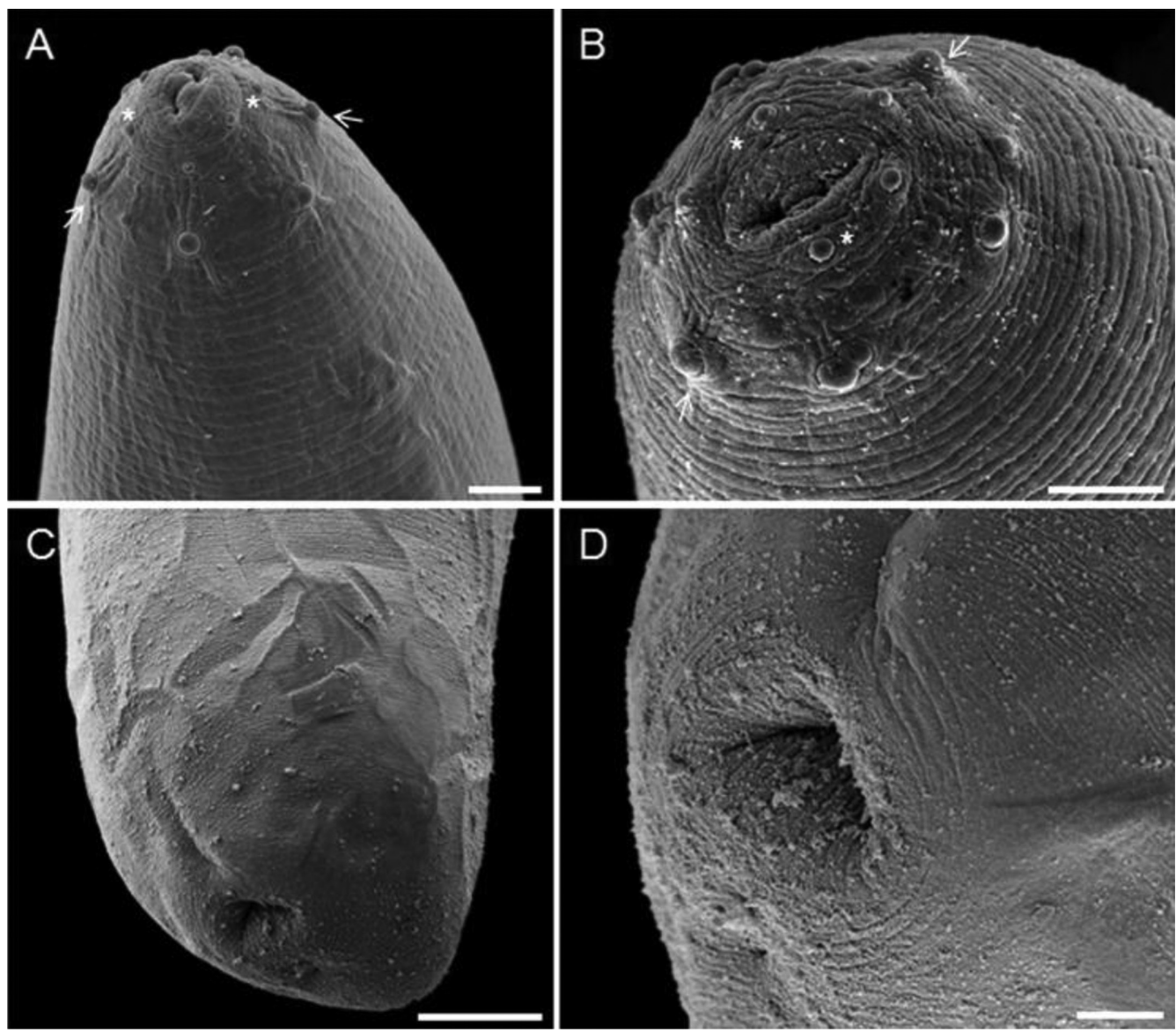

Figure 2. Scanning electron microscopy of Eustrongylides sp. larvae found parasitizing Rhinella marina from Eastern Brazilian Amazon. (A) Overview of the anterior portion of the nematode showing two small lips and the presence of two papillae circles: an inner circle $(*)$ and an outer circle (arrows). Bar $=10 \mu \mathrm{m}$; (B) Detail of anterior end, showing the papillae arrangement: the inner circle $\left(^{*}\right)$ with 6 papillae (3 pairs), consisting of 2 lateral, 2 sub-ventral and 2 sub-dorsal, and the outer circle (arrow) with 4 pairs of papillae, 1 lateral pair, 1 dorsal pair and two sub-ventral pairs, with an odd papilla between the two pairs of sub-ventral papillae. Bar $=5 \mu \mathrm{m}$; (C) Posterior region showing the terminal anus. Bar $=20 \mu \mathrm{m}$; (D) Detail of the terminal anus. Bar $=5 \mu \mathrm{m}$.

The encysted larvae on the serosa of stomach and intestines of $R$. marina from the municipality of Santa Cruz do Arari, eastern Amazonia have characteristics of the genus Eustrongylides, including the presence of six cephalic papillae distributed in an inner circle, eight cephalic papillae distributed in an outer circle and a terminal anus. According to Anderson (2000) and Lezama $\&$ Sarabia (2002), these characteristics are important for diagnosis of the genus Eustrongylides.

The absence of genital primordium in the larvae examined characterises it as in the second developmental stage. According to Lichtenfels \& Pilitt (1986), Moravec (1998) and Xiong et al. (2009), second-stage larvae may have remnant cuticle kept from the first moult at the posterior extremity; and absence of genital primordium; third-stage larvae differ from fourth-stage larvae as the latter present a larger genital primordium, different shape of inner papillae circle and differences in morphometry (fourth stage larvae are larger).

The cephalic papillae of both the inner and outer circles of the Eustrongylides sp. larvae of $R$. marina presented sub-spherical shapes with clear cuticle delineations. These data are different from those reported by Lichtenfels \& Pilitt (1986) and Xiong et al.
(2009), who described cephalic papillae of the inner circle of Eustrongylides presenting large pointed apices, and outer-circle papillae with nipplelike apices.

Eustrongylides sp. larvae found in $R$. marina from the eastern Amazonia have larger outer circle cephalic papillae compared to papillae in the inner circle. Thatcher (2006) used the morphology of these papillae to differentiate E. ignotus and E. tubifex larvae. According to this author, fourth-stage larvae of E. ignotus have larger papillae inner circle cephalic papillae than those in the outer circle, the reverse is observed in to E. tubifex. In addition, third-stage larvae of these two species have opposite characteristics. Thus, Eustrongylides sp. larvae, parasites of $R$. marina, are similar to $E$. ignotus larvae; however, they differ both in the shape of the cephalic papillae and their host, which are domesticated birds of the Anseriformes Order in the latter species.

The morphological characteristics described herein suggest that Eustrongylides sp. may be a different species from E. ignotus and E. tubifex; however, species identification involving larval stage comparisons is complex, given the somewhat confusing taxonomic status of species within the genus Eustrongylides. Then, 
molecular determination of identity is very important as supported by Measures (1988).

This study is the first report of parasitism of second-stage larvae of the genus Eustrongylides in amphibians, and for $R$. marina (Bufonidae) from eastern Amazonia. Larvae of this genus have been reported in other amphibian hosts. Goldberg \& Bursey (2002), Lezama \& Sarabia (2002), Bursey \& Brooks (2010) and Yildirimhan et al. (2012) reported parasitism by Eustrongylides in amphibians of the Ranidae family (Neartic - California, U.S.A), and Kuperman et al. (2004) reported parasitism in amphibians of the Pipidae family (Neartic - California, U.S.A). In Brazil, according to Vicente et al. (1991) Eustrongylides larvae were found in Leptodactylus ocellatus (Leptodactylidae) in the municipality of Salobras, State of Mato Grosso do Sul, Central-West Region of Brazil, in the Pantanal Biome. In fish hosts, those nematodes were first reported by Travassos et al. (1928) parasitising: Callichthys callichthys, Pimelodus clarias, Synbranchus marmoratus, Salminus maxillosus, Pseudoplatystoma sp., Acesthrorhamphus sp., and Poecilia vivipara. Later, Rego \& Vicente (1988a) reported in Auchenipterus nigripinnis, Serrasalmus nattereri, Pirinampus pirinampu, Rhaphiodon vulpinus, Pseudoplatystoma fasciatum and Serrasalmus marmoratus from Cuiabá River, MT; in Hoplias malabaricus from Pirassununga - SP (REGO \& VICENTE, 1988b), Eiras \& Rego (1988) found in Paratrygon sp., Pygocentrus nattereri and P. corruscans from Cuiabá River - MT; from Paraná river, Martins et al. (2009) reports Eustrongylides larvae in Cichla piquiti, Plagioscion squamosissimus and Hoplias malabaricus. In Amazonia, Benigno et al. (2012) described the occurrence of Eustrongylides larvae in the fish species: Hoplerythrinus unitaeniatus, H. malabaricus and Pygocentrus nattereri from Lake Arari (Marajó Archipelago, Pará) and Meneguetti et al. (2013) report Eustrongylides sp. in Hoplias malabaricus from Rondônia.

Eustrongylides larvae can cause a zoonotic infection known as human eustrongylidosis. The transmission occurs through the consumption of raw or undercooked fish meat and clinical presentations in humans may range from stomach inflammation to intestinal perforation requiring surgical removal of helminths (EBERHARD et al., 1989). Thus, records of the occurrence of Eustrongylides larvae in Amazon region are important, especially considering that the Eastern Amazon region has an extensive hydrographic basin and a large riverside population that use fish as their main food source.

Measures (1988) stated that the adult stage of nematodes of the genus Eustrongylides occurs mainly in Ciconiformes, Podicipediformes, Pelecaniformes, Gaviiformes and Anseriformes birds. Among these orders, Eustrongylides parasitism has been reported in Ciconiformes in Brazil; additionally, Vicente et al. (1995), reports some Ciconiformes bird parasitized by Eustrongylides in the Marajó Archipelago. Valente et al. (2011) described other piscivorous birds of the Acciptitriformes (Pandionidae family) and Charadriiformes (Laridae and Sternidae families) in the same Archipelago. Phalacrocorax brasilianus brasilianus was found as a definitive host for Eustrongylides nematodes in South of Brazil (MONTEIRO et al., 2011), thus, as it is also a common fish-eating bird species in Amazon region, it should be considered as a potential definitive host for Eustrongylides nematodes in that area. These birds, due to their feeding habits, may participate in the biological cycle of Eustrongylides in the region. In addition, the presence of migratory birds may facilitate dispersal among areas of the Amazonia region and to other countries in the Americas.

Then, as crocodiles, alligators, crows, white-faced herons, kites, eagles, bush stone-curlews, tawny frogmouths, water rats, giant white-tailed rats and snakes are natural predators of Rhinella marina (ZUG \& ZUG, 1979; BRANDT \& MAZZOTTI, 2009), we present here for the first time, the marine toad as a intermediate/ paratenic host in the biological cycle of Eustrongylides. This is the first report of these nematodes in Bufonidae from Marajó Archipelago, eastern Amazonia and adds another species to the known helminth parasites of $R$. marina in Brazil and in the Neotropical Region.

\section{Acknowledgements}

The authors thank Dr. Paulo Pimenta of the René Rachou Research Institute, Oswaldo Cruz Foundation - Mina Gerais, Brazil for technical support in Scanning Electron Microscopy techniques. Financial support for this study was provided by the PROPESP/ PPGBAIP/UFPA; CAPES Foundation, the Ministry of Education of Brazil (grants CAPES -PARASITOLOGIA BÁSICA/2010 and PROCAD-NF 2009), the National Council for Scientific and Technological Development (CNPq) (CNPq Research grant of productivity of JNS; grants SISBiota 2010-Sistema Nacional de Pesquisa em Biodiversidade - number 563355/2010-7, PVE CAPES/CNPq A_033/2013). This study is part of Institutional Scientific Initiation Scholarship Program (PIBIC) of CSBM at Federal University of Pará.

\section{References}

Anderson RC. Nematode parasites of vertebrates: Their development and transmission. 2nd ed. Wallingford: CAB International; 2000.

Benigno RNM, Clemente SCS, Matos ER, Pinto RM, Gomes DC, Knoff M. Nematodes in Hoplerythrinus unitaeniatus, Hoplias malabaricus and Pygocentrus nattereri (Pisces, Characiformes) in Marajó Island, Brazil. Rev Bras Parasitol Vet 2012; 21(2): 165-170. http://dx.doi.org/10.1590/ S1984-29612012000200018. PMid:22832760.

Brandt LA, Mazzotti FJ. Marine Toads (Bufo marinus). Gainesville: University of Florida; 2009.

Bursey CR, Brooks DR. Nematode parasites of 41 anuran species from the Area de Conservación Guanacaste, Costa Rica. Comp Parasitol2010; 77(2): 221-231. http://dx.doi.org/10.1654/4418.1.

Eberhard ML, Hurwitz H, Sun A, Coletta D. Intestinal perforation caused by larval Eustrongylides (Nematoda: Dioctophymatoidae) in New Jersey. Am J Trop Med Hyg 1989; 40(6): 648-650. PMid:2742040.

Eiras JC, Rego AA. Histopatologia da parasitose de peixes do rio Cuiabá (Mato Grosso) por larvas de Eustrongylides sp. (Nematoda, Dioctophymidae). Braz J Biol 1988; 48: 273-280.

Friend M, Franson JC. Field manual of wildlife diseases. Madison: US Geological Survey; 1999.

Goldberg SR, Bursey CR. Helminths of the bullfrog, Rana catesbeiana (Ranidae), in California with revisions to the California anuran helminth list. Bull South Calif Acad Sci 2002; 101(3): 118-130. 
Gomes TF, Melo FTV, Giese EG, Furtado AP, Gonçalves EC, Santos JN. A new species of Mesocoelium (Digenea: Mesocoeliidae) found in Rhinella marina (Amphibia: Bufonidae) from Brazilian Amazonia. Mem Inst Oswaldo Cruz 2013; 108(2): 186-191. http://dx.doi.org/10.1590/00740276108022013010 . PMid:23579798.

Kuperman BI, Matey VE, Fisher RN, Ervin EL, Warburton ML, Bakhireva $\mathrm{L}$, et al. Parasites of the African clawed frog, Xenopus laevis, in Southern California, U.S.A. Comp Parasitol 2004; 71(2): 229-232. http://dx.doi. org/10.1654/4112.

Lezama JR, Sarabia DO. Histological lesions in skeletal muscle, caused by Eustrongylides sp. (Nematoda: Dictiophymatoidae) larvae in edible frogs from Lake Cuitzeo, in the state of Michoacan, in Mexico. Veterinaria (Mex) 2002; 33(3): 335-341.

Lichtenfels JR, Pilitt PA. Eustrongylides sp. (Nematoda: Dioctophymatoidea): differentiation of third- and fourth-stage larvae from killifish, Fundulus sp., collected in Chesapeake Bay area, U.S.A. Proc Helminthol Soc Wash 1986; 53(1): 144-148.

Martins ML, Santos RS, Marengoni NG, Takahashi HK, Onaka EM. Seasonality of Eustrongylides sp. (Nematoda: Dioctophymatidae) larvae in fishes from Paraná river, South-western Brazil. B Inst Pesca 2009; 35(1): 29-37.

Measures LN. Epizootiology, pathology, and description of Eustrongylides tubifex (Nematoda: Dioctophymatoidea) in fish. Can J Zool 1988; 66(10): 2212-2222. http://dx.doi.org/10.1139/z88-329.

Melo FTV, Giese EG, Furtado AP, Soares MJ, Gonçalves EC, Vallinoto AC, et al. Lanfrediella amphicirrus gen. nov. sp. nov. Nematotaeniidae (Cestoda: Cyclophyllidea), a tapeworm parasite of Rhinella marina (Linnaeus, 1758) (Amphibia: Bufonidae). Mem Inst Oswaldo Cruz 2011; 106(6): 670-677. http://dx.doi.org/10.1590/S0074-02762011000600005. PMid:22012220.

Meneguetti DUO, Camargo LMA, Laray MPO. Primeiro relato de larvas de Eustrongylides sp. (Nematoda: Dioctophymatidae) em Hoplias malabaricus (Characiformes: Erythrinidae) no Estado de Rondônia, Amazônia Ocidental, Brasil. Rev Pan-Amaz Saude 2013; 4(3): 55-58. http://dx.doi.org/10.5123/S2176-62232013000300008.

Monteiro CM, Amato JF, Amato SB. Helminth parasitism in the Neotropical cormorant, Phalacrocorax brasilianus, in southern Brazil: effect of host size, weight, sex, and maturity state. Parasitol Res 2011; 109(3): 849855. http://dx.doi.org/10.1007/s00436-011-2311-x. PMid:21431903.

Moravec F. Nematodes of freshwater fishes of the neotropical region. Praha: Academia; 1998.

Moravec F. Parasitic nematodes of freshwater fishes of Europe. Dordrecht: Kluwer Academic Publishers; 1994.

Rego AA, Vicente JJ. Excursão cientifica a zona do Pantanal, Estado de Mato Grosso, para coleta de helmintos. Cienc Cult 1988a; 40(1): 65-68.
Rego AA, Vicente JJ. Eustrongylides ignotus Jägerskiöld, 1909 (Nematoda: Dioctophymatoidea), parasito de peixes, anfíbios, répteis e aves: distribuição e taxonomia. Cienc Cult 1988b; 40(5): 478-483.

Santos JN, Giese EG, Maldonado A Jr, Lanfredi RM. A new species of Oswaldocruzia (Molineidae: Nematoda) in Chaunus marinus (Amphibian: Bufonidae) (Linneaus, 1758) from Brazil. J Parasitol 2008; 94(1): 264268. http://dx.doi.org/10.1645/GE-1336.1. PMid:18372649.

Santos JN, Melo FTV, Nascimento LCS, Nascimento DEB, Giese EG, Furtado AP. Rhabdias paraensis sp. nov.: a parasite of the lung of Rhinella marina (Amphibia: Bufonidae) from Brazilian Amazonia. Mem Inst Oswaldo Cruz 2011; 106(4): 433-440. http://dx.doi.org/10.1590/ S0074-02762011000400008. PMid:21739030.

Silva JP, Melo FTV, Silva LCN, Gonçalves EC, Giese EG, Furtado AP, et al. Morphological and molecular characterization of Ortleppascaris sp. larvae, parasites of the cane toad Rhinella marina from eastern Amazonia. J Parasitol 2013a; 99(1): 118-123. http://dx.doi.org/10.1645/GE-3203.1. PMid:22924910.

Silva JP, Silva DCB, Melo FTV, Giese EG, Furtado AP, Santos JN. Liver histopathology in the cane toas, Rhinella marina (Amphibia: Bufonidae), induced by Ortleppascaris sp. larvae (Nematoda: Ascarididae). J Parasitol 2013b; 99(2): 250-256. http://dx.doi.org/10.1645/GE-3215.1. PMid:22989059.

Thatcher VE. Aquatic biodiversity in Latin America: Amazon fish parasites. 2nd ed. Sofia: Pensoft; 2006.

Travassos L, Artigas PT, Pereira C. Fauna helmintológica dos peixes de água doce do Brasil. Arch Inst Biol 1928; 1: 5-67.

Valente RM, Silva JMC, Straube FC, Nascimento JLX. Conservação de aves migratórias neárticas no Brasil. Belém: Conservação Internacional; 2011.

Vicente JJ, Rodrigues HO, Gomes DC, Pinto RM. Nematóides do Brasil $2^{a}$ parte: Nematóides de anfíbios. Rev Bras Zool 1991; 7(4): 549-626. http://dx.doi.org/10.1590/S0101-81751990000400015.

Vicente JJ, Rodrigues HO, Gomes DC, Pinto RM. Nematóides do Brasil. Parte IV. Nematóides de aves. Rev Bras Zool 1995; 12(1): 1-273. http:// dx.doi.org/10.1590/S0101-81751995000500001.

Xiong F, Wang GT, Wu SG, Nie P. Development of Eustrongylides ignotus (Nematoda: Dioctophmida) in domestic ducks (Anas platyrhynchos domestica (L.)). J Parasitol 2009; 95(5): 1035-1039. http://dx.doi.org/10.1645/ GE-2057.1. PMid:19463029.

Yildirimhan HS, Sumer N, Incedogan S, Bursey CR. Helminth parasites of the lemon-yellow tree frog, Hyla savignyi (Hylidae), from Turkey. Turk J Zool 2012; 36(2): 171-184.

Zug GR, Zug P. The Marine Toad, Bufo marinus: a natural history resumé of native populations. Washington: Smithsonian Institution Press; 1979. 